\title{
Análise do SI 8: A temática da criação
}

Orientador: Leonardo Agostini Fernandes

Mestrando: Rafael Raymundo Schmidt

Área de Concentração: Teologia Bíblica

Linha de Pesquisa: Análise e Interpretação de Textos do Antigo e Novo Testamento

Projeto de Pesquisa: Temas inerentes ao Pentateuco

O Sl 8, objeto de estudo da presente pesquisa, é uma poesia que descreve um aspecto da criação, como um louvor descritivo, emoldurado por um refrão corálico. O S1 8 se dirige a YHWH sempre na segunda pessoa, com exaltações inesgotáveis. Apresenta a figura do homem de maneira central no poema, sem no entanto ofuscar a centralidade de YHWH no que tange sua posição dentro do S1 8. Enquanto unidade poética, o Sl 8 estrutura-se em duas seções (vv. 1-5 e vv. 6-10), as quais possuem nuances bem específicas, e patentes devido a sua métrica. A primeira seção é iniciada com uma exaltação plural (v.2), que poderia ser a comunidade manifestando sua exaltação a YHWH, tem uma alternância para o singular no v.4, como o louvor de um indivíduo, e retoma a exaltação plural no v.10. Como parte do livro dos Salmos, que pode ser entendido como uma retribuição humana a Deus, o caráter doxológico é sempre muito presente, principalmente nos Salmos onde se referem a criação, visto que é sempre entendida como uma manifestação da grandiosidade do Deus de Israel, que tudo criou. O Sl 8 apresenta então a criação de YHWH para o homem, e o homem devendo remeter-se sempre a YHWH.

Palavras-chave: Salmo 8. Exegese. Criação. Criador. 